Canadian and International Education

Vol. 31, No. 2, December 2002.

(c) Comparative and International Education Society of Canada

\title{
International Comparisons of Education Systems
}

\author{
Nelly McEwen \\ Alberta's Commission on Learning
}

\begin{abstract}
This article introduces the Canadian and International Education journal's special issue on international comparisons of education systems featuring OECD's Indicators of Education Systems (INES). The special issue originates from a symposium on intermational indicators at the conference of the Canadian Society for the Study of Education in Toronto in May 2002. The introduction discusses the development of indicators worldwide, followed by a description of the establishment of INES. It then looks at the conceptual framework underlying this OECD program and a brief description of INES today. Finally, it provides a synopsis of what follows in the subsequent articles designed to inform the reader of the current work of this internationally collaborative program.
\end{abstract}

\section{Introduction}

Interest in international comparisons has its origins in cross-national studies of student achievement in the early 1960s. The International Association for the Evaluation of Educational Achievement (IEA) introduced cross-national studies, which generated public interest in international comparisons that has grown steadily over the past four decades. In a retrospective look at IEA, Torsten Husén (1996), one of the founding fathers of IEA, described lessons from the first two decades of cross-national studies. IEA was established in 1961 as a forum for scientific exchange and incorporated in 1968. It originated from a desire to conduct an empirical study of the cognitive development of children from different national systems of education in response to concerns about the quality of secondary education in general and science education in particular which began to be raised in the late 1950s. Researchers from a predominantly neopositivist background collaborated to launch a feasibility study to find out 
whether it was methodologically feasible and administratively possible to develop instruments that were cross-nationally valid and could be administered uniformly over a range of countries with different school systems.

The Organization for Economic Cooperation and Development (OECD) made a first attempt to develop indicators in the early 1970s. Bottani and Tuijnman (1994) indicated that several factors explained the quick demise of this early OECD project. Perhaps the central reason was that it did not seek to establish a direct relationship between the indicator data and the main policy interests of that period. The indicators movement consequently failed to enlist and sustain the support of policy makers, because it was unable to convince them that the indicators would offer unambiguous, timely and policy-sensitive information on the functioning of education systems.

The debate and the reform movement following the release of $A$ Nation at Risk (United States National Commission on Excellence in Education, 1983) had a major impact on the perception of the usefulness of aggregate data on aspects of education finance, organization, enrolments and outcomes. In the late 1980 s and early 1990s, the publication of the results of IEA's large-scale international surveys focused the attention of both the public and decision makers on the outcomes of education. The evaluation of student and school performance, the monitoring of the functioning of education systems, the guidance of educational policies and the improvement of resource management became central issues in the political forum. Parallel to the increase in attention paid to the outcomes of education, politicians shifted from issues in managing the quantitative growth of the system to school improvement Accordingly, student achievement became a key criterion for judging the quality and effectiveness of the education system (Bottani \& Tuijnman, 1994).

The 1980 s educational reform movement began in reaction to perceived shortcomings in education and international competition in all sectors. This worldwide movement led to expectations for greater accountability and an increase in monitoring and evaluation of schools and systems. The search for meaningful information to help improve education led organizations to develop and implement indicator systems. An extensive body of literature on indicator systems as a tool for reform and accountability emerged. For example, an annotated bibliography prepared for Alberta's Educational Quality Indicators initiative (Alberta Education, 1990) contained 350 citations organized 
into 14 themes under three major headings: indicator systems, interpretative framework, and outcomes. Much has been written on the subject since.

Several models of indicator systems exist. (See, for example, Oakes, 1986; Shavelson, McDonnell, Oakes, Carey, \& Picus, 1987; McEwen, \& Zatko, 1989; Nuttall, 1990). They are all variations of a context, input, process, outcome model. These and other authors have recommended the use of multiple goals of education (based on appropriate dimensions and domains of schooling), multiple indicators of each goal measured by multiple methods, multiple levels of analysis (student, class, school, system, province), and multiple participants (government, administrators, teachers, academics, parents). An indicator system should be rooted in a conception of the important components of the operation and outcomes of schooling, and be based on the goals, priorities, and expectations of its originators (McEwen \& Chow, 1991).

Torney-Purta (1990) suggested that the purpose of international comparisons is to build a structure to facilitate policy makers' learning from other countries' successful educational programs and better understanding of the processes that lead to excellence. Participation is partly a matter of national competitive interests; it also reflects broader interests in the political, social, and economic advantages of highquality education and educational research throughout the world.

Three special issues of the International Journal of Educational Research have featured national and international indicators (Windham, 1988; Bottani \& Delfau, 1990; McEwen, 1996). They have addressed the relevance of effectiveness indicators, national and international efforts to develop indicator systems, and the uses, issues, and implications of national and international indicators of educational performance. If indicators are to inform national policy, they must provide important, relevant, and actionable information. Choices among policy options are based on which policy works best. Indicators provide information about the performance or health of the education system and help to raise relevant policy questions. Both quantitative and qualitative methods are needed to capture a broader range of indicators. Since an indicator system is a tool for reform and improvement, it must encompass the important goals and attributes of an education system if it is to point to viable policy alternatives. While academic achievement has been the major indicator of student leaming. other areas must be addressed if a more comprehensive picture of 
student success is desired. Moreover process indicators can suggest improvements to the education system and should be added to the contextual and financial indicators that currently predominate. The need for standard definitions was also raised (McEwen, 1996).

Several themes emerge from the national and international experiences. These include the need for policy relevance, a broader range of indicators, standard definitions, capacity and effort. Priorities for developing the next generation of performance indicators include a concerted effort to develop indicators where none currently exist, greater policy analysis, and the need to improve the validity, reliability, utility, and comparability of indicators (McEwen, 1996).

The focus on achievement generated by the IEA studies and the pivotal role achievement plays in the current worldwide attention on accountability accord this indicator preeminence. Table 1 presents a summary of the major achievement studies over the past four decades.

\section{The Establishment of INES}

The changed political context in the 1980 s led to a new attempt to establish international indicators. OECD initiated the Indicators of Education Systems (INES) Project as a consequence of growing dissatisfaction with the disparity between the simplicity of instruments and definitions used for international data, and the perceived complexity of education and training realities (Bottani, 1996). Decision makers in several countries required the means to compare the performance of their education systems with those of other countries, to better assess their effectiveness and monitor their evolution. The type and quality of data available were not appropriate to achieve these aims. OECD deployed substantial and increasing efforts to gather, process, improve, and report statistics and indicators about education and related fields.

OECD sponsored two international conferences designed to clarify the issues involved in developing international indicators. The first, hosted by the U.S. Government in Washington, DC in November 1987, focused on the role of performance indicators, while the second, initiated by the French authorities in March 1988 and held in Poitiers, explored the role of indicators in evaluation. Both conferences confirmed the urgent need for better and more comprehensive information about the outcomes of education. 
Table 1: Comparative International Assessments of Educational Outcomes, 1960 to Present

\begin{tabular}{|c|c|c|c|c|}
\hline Name & $\begin{array}{l}\text { Number of } \\
\text { Countries }\end{array}$ & Population & $\begin{array}{c}\text { Data } \\
\text { Collection }\end{array}$ & Domain(s) \\
\hline Feasibility Study & 12 & LS & 1960 & $\begin{array}{l}\text { Mathematics, science, reading, } \\
\text { comprehension, geography, non- } \\
\text { verbal reasoning }\end{array}$ \\
\hline $\begin{array}{l}\text { First Intermational Mathematics Study } \\
\text { (FIMS) }\end{array}$ & 13 & LS, US & 1964 & Mathematics \\
\hline Six Subject Survey & $\begin{array}{l}10-19 \\
\text { (depending on } \\
\text { subject) }\end{array}$ & P, LS, US & 1971 & $\begin{array}{l}\text { Science, reading comprehension, } \\
\text { literature, civic education, and } \\
\text { English and French as foreign } \\
\text { languages }\end{array}$ \\
\hline $\begin{array}{l}\text { Second Intemational Mathematics Study } \\
\text { (SIMS) }\end{array}$ & 20 & LS, US & $1982-83$ & Mathematics \\
\hline $\begin{array}{l}\text { Second Intemational Science Study } \\
\text { (SISS) }\end{array}$ & 24 & P, LS, US & $1983-84$ & Science \\
\hline $\begin{array}{l}\text { Intermational Study of Achievement in } \\
\text { Written Composition }\end{array}$ & 14 & P, LS, US & $1984-85$ & Writing \\
\hline $\begin{array}{l}\text { International Assessment of Educational } \\
\text { Progress (IAEP 88) }\end{array}$ & 6 & LS & 1988 & Mathematics and science \\
\hline $\begin{array}{l}\text { International Assessment of Educational } \\
\text { Progress (IAEP 91) }\end{array}$ & $\begin{array}{c}\text { 9-20 } \\
\text { (depending on } \\
\text { subject) }\end{array}$ & P, LS & 1991 & $\begin{array}{l}\text { Mathematics, science, and } \\
\text { geography (optional) }\end{array}$ \\
\hline Reading Literacy Study & 32 & P, LS, US & $1990-91$ & Reading literacy \\
\hline
\end{tabular}




\begin{tabular}{|c|c|c|c|c|}
\hline $\begin{array}{l}\text { International Adult Literacy Survey } \\
\text { (IALS) }\end{array}$ & 12 & \multirow{2}{*}{$\mathbf{A}$} & $\begin{array}{c}1994-95 \\
1996\end{array}$ & \multirow{2}{*}{$\begin{array}{l}\text { Prose, document, and } \\
\text { quantitative literacy }\end{array}$} \\
\hline $\begin{array}{l}\text { Second Intermational Adult Literacy } \\
\text { Survey (SIALS) }\end{array}$ & 8 & & $1997-98$ & \\
\hline $\begin{array}{l}\text { Third International Mathematics and } \\
\text { Science Study (TIMSS) }\end{array}$ & 45 & P, LS, US & $1994-95$ & \multirow{3}{*}{ Mathematics and science } \\
\hline $\begin{array}{l}\text { Third Intemational Mathematics and } \\
\text { Science Study Repeat (TMMSS-R) }\end{array}$ & 38 & LS & 1999 & \\
\hline $\begin{array}{l}\text { Trends in International Mathematics and } \\
\text { Science Study (TIMSS) }\end{array}$ & 50 & P, LS & 2003 & \\
\hline Civic Education Study & 28 & LS & 1999 & $\begin{array}{l}\text { Civics (facts and using } \\
\text { knowledge) }\end{array}$ \\
\hline $\begin{array}{l}\text { Programme for Intemational Student } \\
\text { Assessment (PISA) }\end{array}$ & $\begin{array}{c}32 \\
(2000 \text { cycle) }\end{array}$ & \multirow[t]{2}{*}{ US } & $\begin{array}{l}2000,2003 \\
2006,2009 \\
\end{array}$ & \multirow{2}{*}{$\begin{array}{l}\text { Reading literacy, mathematics } \\
\text { literacy, science literacy, and } \\
\text { cross-curricular competencies }\end{array}$} \\
\hline PISA Plus & 13 & & $2001,2004 \ldots$ & \\
\hline $\begin{array}{l}\text { Adult Literacy and Lifeskills (ALL) } \\
\text { Survey }\end{array}$ & 18 & $\mathbf{A}$ & 2002 & $\begin{array}{l}\text { Prose/document literacy, } \\
\text { numeracy, teamwork, and } \\
\text { analytic reasoning }\end{array}$ \\
\hline $\begin{array}{l}\text { Progress in Reading Literacy Study } \\
\text { (PIRLS) }\end{array}$ & 35 & $\mathbf{P}$ & 2001 & Reading literacy \\
\hline $\begin{array}{l}\text { Second Information Technology in } \\
\text { Education Study (SITES) Module } 3 \text { ** }\end{array}$ & 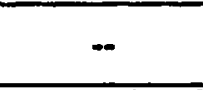 & P, LS, US & 2004 & Information technology skills \\
\hline
\end{tabular}

Key to Population Column: P = Primary, LS = Lower Secondary, US = Upper Secondary, A = Adult.

Source: Owen, Stephens, Moskowitz \& Gil (2000, pp. 7-19); updated 2002. 
On the basis of these conferences and the issues they raised, the Governing Board of OECD's Centre for Educational Research and Innovation (CERI) approved a research project in May 1988. The exploratory work undertaken to demonstrate the interest in and feasibility of education indicators was reviewed in Semmering in September 1989 at the first General Assembly of project participants hosted by the Austrian authorities. The overall positive assessment the work received led to the second phase of the INES Project, and it is the results of this phase that were discussed at the second General Assembly in Lugano (Alexander, 1994).

Phase I of the INES Project, from June 1988 to December 1989, examined the feasibility of developing and constructing comparable indicators in OECD countries. The conclusion was that it was not only possible, but also desirable to assemble an international set of indicators in education. Phase I aimed to: develop a preliminary exploration of a set of key indicators provided by the participating countries; provide a forum for exchange about the development of indicators and their use in educational policy and management; and contribute to evaluation methodology, indicator development, and understanding of the use, relations, and limitations of education indicators (Bottani \& Walberg, 1992). Phase I confirmed the need for an indicators system and demonstrated its feasibility. The most complex problem was the classification of concepts. The aim was not to create international rankings but rather to provide national policy makers with a broader understanding of the factors influencing the quality of education and to permit them to explore a wider range of policy options.

The risks and factors that caused the decline of the social indicators movement in the United States during the late 1960s and early 1970s clearly also posed a potential threat for the OECD education indicators. Fortunately, the participants and delegates attending the Lugano General Assembly of the INES project in September 1991, after a long, lively and sometimes difficult debate, decided to publish a first set of international education indicators - despite the certainty that errors would occur, that many important areas would not be covered, and that it would be difficult to avoid misleading interpretation (Bottani \& Tuijnman, 1994).

Between 1992 and 1995, OECD produced three sets of education indicators that can be considered as successively improved editions of an "ideal" set of indicators approved by member countries in 1991 after 
three years of preparatory work. The first edition of Education at a Glance (EAG), published in 1992, contained 36 indicators (OECD, 1992a). The second and third editions (OECD, 1993; 1995) contained 38 and 49 indicators respectively, distributed over the three major categories: resources and processes (the largest number), context, and results.

\section{INES Conceptual Framework}

From the beginning of the INES project, discussions focused on the conceptual framework for organizing the set of indicators. The choices before 1991, which influenced the construction of the first three sets of indicators, were described in two publications: The $O E C D$ International Education Indicators. A Framework for Analysis (OECD, 1992b) and Making Education Count. Developing and Using International Indicators (OECD, 1994).

The aims of the CERUOECD Project embraced both international comparisons and international cooperation in the development of better local indicator systems. Given the criticisms of earlier work, a comprehensive framework for the development and interpretation of indicator systems was essential, and the project adopted the following systemic scheme (Nuttall, 1992, p. 19).

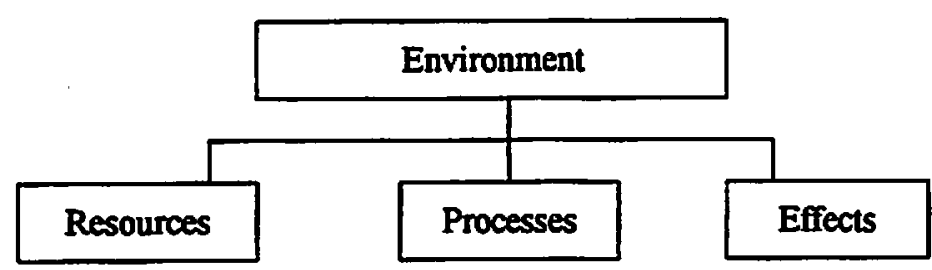

Under the direction of the Scientific Advisory Group, the work of the preliminary phase of the project was undertaken by five Networks of interested countries focusing on more circumscribed aspects of the general frameworks:

1. flow of students through the education system

2. students' outcomes, including attainments

3. schools and the environment

4. the costs of education

5. attitudes and expectations 
In the first phase, each network investigated the feasibility of deriving and calculating a set of international education indicators. In all networks, the project provided a valuable forum for the exchange of information about methods and practices of developing and using education indicators for monitoring, policy making and managing education systems (p. 20).

The conceptual models that preceded the development of INES are important in placing the frame and the work of the project in context. In a review of conceptual models in use for education indicators, Van Herpen (1992) noted that in the preceding 15 years there had been numerous proposals to develop systems of education indicators. There is some difference among the models, but there is also a large degree of overlap. He analyzed eight conceptual models of education: (1) social indicators, (2) the inductive approach, (3) policy goals focusing on the output of education systems, (4) manipulable input variables, (5) dividing consumption and production, (6) compound indicators, (7) the education system as a whole, and (8) the school as the unit of analysis. The shared basis of these approaches is an input-process-output model. The role of the environment was viewed as an explanatory variable by some researchers and as the effect education has on the environment by others (p. 45).

Van Herpen noted that typologies are often one-sided depending on researchers' interests. Researchers belonging to the effective school movement focus on process indicators, economists on the relationship between input and output, political scientists on steering possibilities, and sociologists on the environment. It is important to find a balanced approach embodying these different outlooks so as to property portray the complex reality of education.

Windham (1988) provided a two-dimensional model for the measurement of the effectiveness of education systems: determinants (inputs and processes) and effects (outputs and outcomes). This approach divides outputs into two parts: direct results and longer-term results. As INES evolved, so did conceptions of its model. See Judit Kádár-Fülöp's article for the current conceptual framework.

\section{INES Today}

General Assemblies are held every five years and set the direction for the next five-year mandate of INES. The third was held in Lahti in 1995 and the fourth in Tokyo in 2000. The INES networks and 
working groups developed a compendium of background documentation for the Tokyo meeting. As well, OECD commissioned evaluations by three external evaluators and invited each member country to comment on progress since the 1995 meeting in Lahti.

The main themes in Tokyo were:

- measuring the quality of education outcomes

- estimating economic and social retums to learning

- identifying key determinants of education success

- applying cross-cutting policy perspectives in the analytical work (OECD, 2000b).

Each theme constitutes one element in an implicit cause-and-effect model of education that includes upstream determinants of quality and downstream impacts of outcomes, the whole against a backdrop of a lifetime view of learning and of a concern for equity. What makes the exercise difficult is that effects, whether educational outcomes or as a result of these, tend to be multiply determined, so that it may be difficult to determine precisely what contributes to what and to what degree (OECD, 2000b). A brief synopsis of the work of each network follows.

In 1995, member countries encouraged OECD to develop intemational benchmarks. In response, Network $A$ began to develop a data strategy that would provide regular, policy driven data on student achievement. Implementation of the strategy began in 1997 and the data collection for the first PISA survey cycle was successfully completed in 2000 (OECD, 2000a; 2001).

The mandate of Network B is the role of education and training outside of the formal education system. There is implicit recognition of the nature of education as "a public good". International comparisons provide the means to assess how well education contributes, to a greater or lesser degree, to furthering socio-economic outcomes including educational attainment, labor force status by educational attainment, and education and earnings.

Network $\mathrm{C}$ is responsible for developing indicators that peer into the "black box" linking educational inputs and outputs. Such indicators should reveal some of the key characteristics in the learning environment and the organization of schools than can lead to effective educational practice. While it is impossible for process indicators to describe explicitly how educational resources should be most 
efficiently employed, they do give policy makers the opportunity to examine and evaluate alternative models of educational organizations.

The Technical Group focuses on costs and human resource access to and participation in education, student stocks and flows, and the graduate output of educational institutions. These are essentially education statistics. A fifh network, focusing on attitudes and expectations, was suspended in 1997.

OECD introduced a new thematic publication, Education Policy Analysis (EPA), in 1996 to provide further analysis of selected results in the EAG publications (OECD, 1996). In 1997, the launch of the Programme for International Student Assessment (PISA) meant that OECD would have a regular source of achievement data for publication. In 2002, OECD released the $9^{\text {th }}$ edition of EAG and the $6^{\text {th }}$ edition of EPA. Table 2 provides a brief history of the development of INES and the OECD indicators.

As an external evaluator of the work of INES from 1995 to 2000, Jeanne Griffith (2000) indicated that the strength of indicators is that they focus attention on critical issues. They are selected from a wealth of detailed statistical information because they convey important information about key policy-relevant issues. Because of this, they can, in themselves, become levers for change. They work as tools for reform. Policy makers use indicators to identify issues, to serve as focal points for discussion with their constituents and each other, and to benchmark systemic improvements. She indicated that since Lahti, key agreement was reached in the areas of objectives, management principles, and operational structures. She concluded that the initially focused vision of INES to produce a set of international education indicators that would be policy-relevant, of high statistical quality, and with uniform data across countries, has grown. The vision now encompasses an ongoing research program to promote continued improvement of intemational data available for policy makers and the public in an ongoing education debate. Furthermore, she believes that on balance INES is a critically important program that has far surpassed expectations. Indeed its products have become OECD's best sellers.

Education at a Glance is now published in five languages: English, French, German, Spanish, and Japanese. 
Table 2: A Brief History of the Development of INES and OECD Indicators

\begin{tabular}{|c|c|c|}
\hline Year & $\begin{array}{l}\text { Developmental } \\
\text { Conferences } \\
\& \text { General Assemblies }\end{array}$ & OECD Publications \\
\hline 1987 & $\begin{array}{l}\text { Washington, DC, United } \\
\text { States }\end{array}$ & \\
\hline $\begin{array}{l}1988 \\
1989 \\
1991\end{array}$ & $\begin{array}{l}\text { Poitiers, France } \\
1^{\text {th }} \mathrm{GA} \text { in Semmering, Austria } \\
2^{\text {nd }} \mathrm{GA} \text { in Lugano, } \\
\text { Switzerland }\end{array}$ & \\
\hline 1992 & & $\begin{array}{l}\text { The OECD International } \\
\text { Education Indicators } \\
1^{\text {th }} \text { Education at a Glance } \\
\text { (EAG) }\end{array}$ \\
\hline $\begin{array}{l}1993 \\
1994\end{array}$ & & $\begin{array}{l}2^{\text {nd }} \text { EAG } \\
\text { Making Education Count }\end{array}$ \\
\hline 1995 & $3^{\text {rd }} \mathrm{GA}$ in Lahti, Finland & $\begin{array}{l}3^{\text {rd }} \text { EAG, Meassuring What } \\
\text { Students Learn }\end{array}$ \\
\hline 1996 & & $\begin{array}{l}4^{\text {th }} \text { EAG, } 1^{\text {a }} \text { Education Policy } \\
\text { Analysis (EPA) }\end{array}$ \\
\hline $\begin{array}{l}1997 \\
1998 \\
1999\end{array}$ & Launch of PISA* & $\begin{array}{l}5^{\text {th }} \mathrm{EAG}, 2^{\text {nd }} \text { EPA } \\
6^{\text {th }} \mathrm{EAG}, 3^{\text {th }} \text { EPA } \\
4^{\text {th }} \text { EPA, CD-ROM of OECD } \\
\text { education database }\end{array}$ \\
\hline 2000 & $4^{\text {th }}$ GA in Tokyo, Japan & $\begin{array}{l}7^{\text {th }} \text { EAG, INES Compendium } \\
\text { online dissemination system }\end{array}$ \\
\hline $\begin{array}{l}2001 \\
2002\end{array}$ & & $\begin{array}{l}8^{\text {th }} \text { EAG, } 5^{\text {th }} \text { EPA } \\
9^{\text {th }} \text { EAG, } 6^{\text {th }} \text { EPA }\end{array}$ \\
\hline
\end{tabular}

Sources: OECD, 1992; 2000b.

*PISA - OECD's Programme for International Student Assessment

International Comparisons of Education Systems

This final section provides a synopsis of the articles comprising this special issue of Canadian and International Education. Each article focuses on the work of the particular network, within the context of INES. One article focuses on the impact of INES in a particular country, and another is a discussion of the set of articles. My final article summarizes the purposes and policy relevance of INES and reflects on and suggests some future directions. 
Judit Kádár-Fülöp describes the structure and framework of INES. The current conceptualization of the INES framework is a 12-cell matrix of participants by outputs and outcomes, policy levers and contexts, and antecedents and constraints. Data are collected through the three networks (A, B, and C) and the Technical Group. She discusses the impact and uses of INES: (1) supporting policy evaluation and policy research; (2) policy debates on education issues; (3) the learning enterprise; (4) development of intemational databases; (5) improvement of national information systems in education; and (6) partnerships among and within countries.

Eugene Owen, Jay Moskowitz, and Maria Stephens focus on measuring learner outcomes. They begin by setting the context for Network A, followed by early developmental work. They give particular attention to the development of PISA and detail initial findings from PISA 2000 on students' overall performance in reading literacy and on the variation between and within schools in reading literacy. The PISA results were published in EAG 2002.

Patrice de Broucker describes and discusses the work of Network B, which focuses on education and socio-economic outcomes. He provides indicators for educational attainment, rates of return for university education, and intergenerational educational attainment. Currently the network is concentrating its efforts in four areas: schoolto-work transitions, continuing education and training, human and social capital and equity.

Network $\mathrm{C}$ develops indicators on policy malleable conditions of the learning environment at the system, school, and classroom levels. It has produced indicators on decision-making structures, staffing and the intended curriculum at the system level, and school/classroom processes. Maria Hendriks focuses attention on teachers and the conditions of teaching. The article discusses both conceptual and practical issues, as well as challenges, in teacher indicators that are both policy-relevant and comparable across countries.

Douglas Hodgkinson and Amanda Spencer consider the role of INES in Canada as well as the relevance of the INES indicators from a Canadian perspective. Essentially this is a case study of one of the OECD member countries participating in INES. They report the results of a 1999 survey of the provinces and territories on the uses of the OECD indicators. Canada is a federal system in which each province 
and territory has sole jurisdiction over its education system, resulting in challenges when conceiving of a "national" education system.

Robert Crocker, who served as a discussant for the INES symposium in Toronto, presents his observations on the set of articles. Indicating that the articles present a clear picture of the INES enterprise, he focuses his attention on four areas: the productivity model, narrow measures for broad goals, educational reform, and the relative lack of emphasis on developing analytic relationships. He concludes in the hope that over the next decade, INES will evolve in the direction of broader outcomes measurement, greater attention to process, and the development of greater capacity for modeling educational outcomes and their antecedents.

\section{REFLRENCES}

Alberta Education. (1990). Educational quality indicators: Annotated bibliography. Edmonton: Corporate and Fiscal Planning.

Alexander, T.J. (1994). Introductory address. In Making education count: Developing and using intermational indicators (pp. 13-18). Paris: OECD.

Bottani, N. (1996). OECD international education indicators. International Journal of Educational Research, 25, 279-288.

Bottani, N., \& Delfau, I. (Eds.). (1990). Indicators of the quality of educational systems: An international perspective. International Journal of Educational Research, 34, 321-408.

Bottani, N., \& Tuijnman, A. (1994). International education indicators: Framework, development and interpretation. In Making education count: Developing and using international indicators (pp. 21-35). Paris: OECD.

Bottani, N., \& Walberg, H.J. (1992). What are international education indicators for? In The OECD international education indicators. $A$ framework for analysis (pp. 7-12). Paris: OECD.

Griffith, J.E. (2000). INES - A story of progress. In Report from the extemal evaluators (pp. 2-14). Paris: OECD.

Husén, T. (1996). Lessons from the IEA studies. Intermational Journal of Educational Research, 25, 207-218.

McEwen, N. (Ed.). (1996). Indicators of educational performance. International Journal of Educational Research, 25, 199-288.

McEwen, N., \& Chow, H. (1991). Issues in implementing indicator systems. Alberta Journal of Educational Research, 37, 65-86. 
McEwen, N., \& Zatko, G. (1989, June). Educational quality indicators: Framework for action. Paper presented at the annual meeting of the Canadian Educational Researchers' Association, Quebec City.

Nuttall, D.L. (1990, April). The functions and limitations of international education indicators. Paper presented at the annual meeting of the American Educational Research Association, Boston.

Nuttall, D.L. (1992). The functions and limitations of international education indicators In The $O E C D$ international education indicators. A framework for analysis (pp. 13-23). Paris: OECD.

Oakes, J. (1986). Educational indicators: A guide for policymakers. New Brunswick, NJ: Center for Policy Research in Education, Rutgers University.

OECD. (1992a). Education at a glance. Paris: Author.

OECD. (1992b). The OECD international education indicators. $A$ framework for analysis. Paris: Author.

OECD. (1993). Education at a glance 2. Paris: Author.

OECD. (1994). Making education count: Developing and using international indicators. Paris: Author.

OECD. (1995). Education at a glance 3. Paris: Author.

OECD. (1996). Education at a glance: Analysis. Paris: Author.

OECD. (2000a). Measuring student knowledge and skills. Paris: Author.

OECD. (2000b). The INES compendium. Fourth General Assembly of the OED Education Indicators Programme. Paris: Author.

OECD. (2001). Knowledge and skills for life. First results from PISA 2000. Paris: Author.

Owen, E., Stephens, M., Moskowitz, J., \& Gil, G. (2000). From "horse race" to educational improvement: The future of international education assessments. In INES compendium (pp. 13-26). Paris: OECD.

Shavelson, RJ., McDonnell, L, Oakes, J., Carey, N., \& Picus, L. (1987). Indicator systems for monitoring mathematics and science education. Santa Monica, CA: RAND Corporation.

Torney-Purta, J. (1990). International comparative research in education: Its role in educational improvement in the U.S. Educational Researcher, 19(7), 32-35.

United States National Commission on Excellence in Education. (1983). A nation at risk. Washington, DC: Author.

Van Herpen, M. (1992). Conceptual models in use for education indicators. In The OECD international education indicators. $A$ framework for analysis (pp. 25-51). Paris: OECD 
Windham, D.M. (Ed.). (1988). Effectiveness indicators in the economic analysis of educational activities. International Joumal of Educational Research, 12, 575-666.

Correspondence concerning this article should be addressed to Nelly McEwen, Alberta's Commission on Learning. Email:

Nelly.McEwen@gov.ab.ca 